\title{
Human Resource Management: An Islamic Perspective
}

\author{
K. M. Anwarul Islam ${ }^{1}$ \\ Orobah Ali Barghouthi ${ }^{2}$ \\ ${ }^{1}$ Department of Business Administration, The Millennium University, Dhaka, Bangladesh \\ ${ }^{2}$ Faculty of Business and Economics, Department of Banking \& Finance, Alquds University, Abu Dis, Palestine. \\ Correspondence: Faculty of Business and Economics, Department of Banking \& Finance, Alquds \\ University,Abu Dis, Palestine, E-mail: obargothi@hotmail.com
}

Received: November 24, 2017 Accepted: November 28, $2017 \quad$ Online Published: December 13, 2017

\begin{abstract}
The point of this paper was "Practically equivalent to the different subjects in the board, HR is an exceptional topic as it manages living creatures rather than advertising where the most noteworthy subject is the "item/administration" or business morals where basic leadership in circumstances is the topic.
\end{abstract}

Keywords: HRM, Business Ethics, Islamic Perspective.

\section{Introduction}

Contemporary administration (CM) offers a variety of hypothetical develops inside HR. It is dealt with differently through different schools of thought. These are the logical, traditional social points of view of the board. The logical school of thought saw a laborer (human asset) essentially as a methods for expanding produc $\neg$ tivity and productivity inside a coveted job.The tenets and directions in the logical methodology were extremely inflexible and fundamentally contrived for a strict control on workers. These were intended for most extreme yield, as it were benefit amplification.

The push toward the social point of view or human relations sys-tem is viewed as an advancement from the logical framework toward a more human-situated framework. The point of logical administration was regarding each undertaking as a science wherein the representative was to comprehend the logical method for working; nonetheless, the human relations school recognized that laborers had individual needs.Under the standard of the human relations school, inquire about started on ideas, for example, inspiration at work, authority, cooperation, and correspondence. The essential introduce of concentrate under human relations or the social school as a few researchers like to call it was the conduct of individuals working in gatherings. In any case, the point of both these schools was the means by which to best motivate representatives to perform to the best of their capacities just with the goal that associations could profit the most extreme as far as benefits. The mainstream term utilized at that point to oversee representatives was staff the executives wherein the job of the faculty director was to care for the worker's welfare at work.

A lot later, the term human asset the executives supplanted person $n$ nel the board, and HRM was viewed as "a vital way to deal with man $\neg$ aging business relations which stresses that utilizing individuals' abilities is basic in accomplishing upper hand". 


\section{2, Data Analysis}

Holy Quran and Prophet's Sunnah and, in light of the studies mentioned, I pick the internal locus of control as a successful parameter in management decision making. In this regard, the Holy Quran elucidates the basis and formation of the internal locus of control via the verse below:

Everyone is entangled in the outcome of his deeds.(Quran 74: 38)

This literally implies that one is answerable for one's own actions, thereby stressing the fact that our actions are controlled by us because we are accountable for these.

The faith in Allah (SWT) as the expert, to whom man is liable, underlines that one is in charge of one's own behavior. Consequently the onus of an activity's result as indicated by the Islamic perspective is on the one making the move. This is a vast division in the HR point of view between the two schools of thought. What's more, really a huge one, in light of the fact that the dialog indicates a sensible conclusion, that is, inside the Islamic perspective the main impetus behind human inspiration is inherent inspiration and that the western/contemporary school of thought keeps running on outward inspiration rehearses.

\section{Imam Ali, in Nahjul-Balaghall stated,}

Persist in your action with a noble end in mind.... Failure to perfect your work while you are sure of the reward is injustice to yourself.

This is just in light of the fact that the representative is subject to Allah (SWT), if the association is giving the guaranteed whole, and the worker is rebuked for laxity. He should understand that by being languid or arriving late or not giving the expected time to work, that is, using any and all means, by not performing to his fullest potential he is harrowing harm to himself from that point. It is along these lines anticipated from a specialist to deliver diligent work and effort in the method for acquiring is viewed as a source that washes away one's transgressions, as accentuated in one of the expressions of the heavenly prophet:

Whoever goes to bed exhausted because of hard work, he has thereby caused his sins to be absolved.12 (cited in Abdul-Rauf, 1984, p. 10).

Consequently basically from an Islamic perspective, the highest layer of laborer's inspiration is inborn, that is, the person's responsibility to Allah.

From multiple points of view, this is the key difference between HRM rehearses in western/contemporary and Islamic administration. In the contemporary school of thought, dealing with a workforce requires outer "locus of con-trol." The nonattendance of a solitary, standard methodology of dealing with the work $\neg$ force intimates uniqueness in tenets in different associations, diverse arrangements of codes of practices, guidelines and directions, and responsibility measures crosswise over associations, even inside a similar segment. Numerous a period, there could be an amazing scope of codes, guidelines and gauges, etc set by capable HR chiefs; in any case, the accomplishment of these arrangements is absolutely dependent on how far these are clung to by the representatives and controlled by the managers. 
Just to quickly refresh readers on how this is linked to HR discussion; the issue of standards in conduct is directly linked to one's performance and dominance to work hierarchy, gender, caste, color, and creed priority. It is narrated in the Holy Quran:

O mankind! Truly we have created you male and female and have made you nations and tribes that you may know one another.Indeed the noblest of you in the sight of God is the best in conduct.(49:13)

The Islamic work domain, a man is expected to perform heavy-duty tasks and a woman is relieved of such occupations. The explicit statement on the issue of gender equality is found in the Holy Quran as follows:

Whoever, be it a male or a female, does good deeds and he or she is a believer, then they will enter the Paradise.(Quran 4: 124)

In Chapter 43 in the Holy Quran, it is noted:

We have apportioned among them their livelihood in the life of the world, and raised some of them above others in rank that some of them take labour from others.(Quran 43: 32)

This verse refers to the reality of the social situation in which each individual has a different capacity and different talents: those who are superior in one domain tend to engage the cooperation of or employ others for their ultimate mutual benefit. The clear understanding that can be taken forward for managerial implication from this verse is the levels in an organization.

Holy Quran which is found in Chapter 13:

Allah does not change the condition of people until they change their own condition.(Quran 13:11)

The verse above creates a cause and effect relationship. It clearly explicates that without one's own effort in a given scenario, Allah (SWT) does not simply change man's condition via a miracle.

\section{Conclusion}

Assembling the pieces and practicing self-examination suggests add up to assessment. What's more, on the grounds that the general point is to be close (qurbat) to Allah (SWT) (ought to be comprehended as otherworldly closeness), an evaluation will help the appraisee perceive God. At the point when a man endeavors to get Allah's (SWT) closeness, it in the long run leads him or her to begin familiarizing with the religious principles. Also, as talked about over, one of the religious fundamentals are that inability to consummate your work when you are certain of the reward is injus $\neg$ tice to yourself. Along these lines as cited from Imam Ali, "One who understands one's own self understands his Lord." In the more extensive viewpoint, this is a way to create, improve, and advance one's very own self.

\section{References}

Ciulla, B. J. (1995). Leadership ethics: Mapping the territory. Business Ethics Quarterly 5(1), 5-28.

Conroy, S. J., \& Emerson, T. L. N. (2004). Business ethics and religion: Religiosity as a predictor of ethical awareness among students. Journal of Business Ethics 50, 383-396. 
Danley, J., Harrick, E., Strickland, D., \& Sullivan, G. (1991). HR ethical situations: Human Resources Management $26,1-12$.

Drucker, P. (1954). The Practice of Management. New York, NY: Harper.

Edward, R. (2006). The Enron Scandal: The Crime, Scandal, Tragedy, and Controversy of the Century.Retrieved June 2012, from http://voices.yahoo. com/the-enron-scandal-crime-scandal-tragedy-controversy-136695.html

Group of Translators. (2005). A Brief History of the Fourteen Infallibles. Iran: Ansariyan Publications.

Haykal, M. H., \& Muhammad, H. (1935[1976]). In I. M. El Faruqi (Trans.), The Life of Muhammad.Cairo, Egypt: American Trust Publishers.

Heifetz, R. A. (1994). Leadership Without Easy Answers.Cambridge, MA: Harvard University Press.

Hunt, J. G., \& Conger, J. A. (1999). From where we sit: An assessment of transformational and charismatic leadership research. Leadership Quarterly 10(3), 335-343.

Ibn al-Ukhuwwah, Diya' al-Din Muhammad. (1983). In R. Levy (Trans.), Ma'alim al-Qurbah fi Ahkam al-Hisbah.London: MESSRS Luzak.

Kamel, M., \& Pawan, S. B. (2010). Introduction: Islam and human resource management. Personnel Review 39(6), 685. Quran

\section{Copyrights}

Copyright for this article is retained by the author(s), with first publication rights granted to the journal.

This is an open-access article distributed under the terms and conditions of the Creative Commons Attribution license (http://creativecommons.org/licenses/by/4.0/). 